\title{
Contamination from mercury and other heavy metals in a mining district in Ghana: discerning recent trends from sediment core analysis
}

Jonathan N. Hogarh ${ }^{1 *}$, Ernest Adu-Gyamfi', Daniel Nukpezah², Osei Akoto ${ }^{3}$ and Sam Adu-Kumi4

\begin{abstract}
Background: Many years of gold mining in Ghana has generated huge environmental legacy issues, particularly contamination from heavy metals and metalloids. The present study evaluated the contamination from arsenic (As), cadmium (Cd), copper (Cu), mercury ( $\mathrm{Hg})$ and lead $(\mathrm{Pb})$ in sediment cores at Bibiani, a historical gold mining town in Ghana. The study took a retrospective look at these contaminations by conducting sediment core analysis of heavy metals in sediments collected from Lake Amponsah in the Bibiani district. Sediment cores were sampled to a depth of $30 \mathrm{~cm}$.

Results: The Lake was found to be undergoing sedimentation at an average rate of $1.76 \mathrm{~cm} / \mathrm{y}$. There was marginal decline in Hg concentrations over the past two decades (from the 1990s to 2010s), while the other metals showed relatively increasing trends. The Hg policy restricting Hg usage in Ghana since 1989 has contributed to the recent marginal decline of $\mathrm{Hg}$ in the sediment. It was found that small-scale miners illicitly applied $\mathrm{Hg}$ but used crude retrofits to recover some of the $\mathrm{Hg}$ during the gold amalgamation process. This perhaps contributed to the marginal decline being observed in the sediment compartment with depth. Nevertheless, there was concern of potential risk of exposure to gaseous $\mathrm{Hg}$ during the amalgamation process.
\end{abstract}

Conclusion: Based on findings of this study, Hg legislation in Ghana should be enforced to the latter as it has shown good sign of reducing environmental contamination from this metal.

Keywords: Mercury, Heavy metals, Sediment core, Small-scale mining, Galamsey, Ghana

\section{Background}

Contamination from chemicals remains one of the most serious environmental problems in Ghana, and indeed in most parts of the world. Various activities linked to segments of the Ghanaian economy have been implicated in issues of chemical contamination. For instance, mining operations in Ghana, which predates the 19th century, over the years have caused contamination from heavy metals in the local environment (Bamford et al. 1990; Amonoo-Neizer et al. 1995; Ahmad and Carboo 2000;

\footnotetext{
*Correspondence: jhogarh@gmail.com

1 Department of Environmental Science, College of Science, Kwame

Nkrumah University of Science and Technology, Kumasi, Ghana

Full list of author information is available at the end of the article
}

Antwi-Agyei et al. 2009; Nartey et al. 2012). The applications of pesticides and fertilizers in agriculture, the use of various insecticides for agricultural and public health reasons, as well as poor waste management practices have all introduced various groups of chemical contaminant into the environment in Ghana (Awumbila 1996; Ntow et al. 2006; Obiri-Danso et al. 2011; Hogarh et al. 2014).

A major aspect of the fate of chemical contaminants in the local environment concerns their migration into water bodies, especially via runoffs. This has contributed to widespread contamination of streams, rivers and lakes dotted across the country, with some virtually dying off (Down and Stocks 1978; Asante et al. 2007).
Springer Open

(c) 2016 Hogarh et al. This article is distributed under the terms of the Creative Commons Attribution 4.0 International License (http://creativecommons.org/licenses/by/4.0/), which permits unrestricted use, distribution, and reproduction in any medium, provided you give appropriate credit to the original author(s) and the source, provide a link to the Creative Commons license, and indicate if changes were made. 
Many of these degraded water bodies are either located in the urban centres or within enclaves of mining activities. In Accra, the capital city of Ghana, there has been huge investment to dredge the Odaw River, for example, to bring it back to life. This has however proved elusive due to recurrent inflows of both chemical and biological stressors among other environmental pollutants. Similarly, the Densu River, which supplies parts of Accra with drinking water, is reportedly heavily polluted along its tributaries such that the Ghana Water Company has complained of increased cost of treating drinking water from this source. In rural communities, the main threats endangering the sanctity of water bodies have emanated from mining and agricultural practices (Donkor et al. 2005, 2006a; Bortey-Sam et al. 2015).

The pollution of rivers and lakes from chemicals leads to accumulation of these chemicals in sediment. Thus, sediments act as a major sink of chemical pollutants such as heavy metals (Audry et al. 2004). Sediments therefore contain an environmental record of pollutants that can be useful to help establish retrospectively the pollution history of an area. Sediments build up gradually in a water body, such that older sediments are locked up in deeper layers while recent sediments are in upper layers. Potentially, past contaminations would remain buried with older sediments and recent contaminations associated with upper layer sediments. Provided a water body has not been dredged, a drilled sediment core could provide a good spectrum of pollution dynamics in a watershed (Spencer and MacLeod 2002). Many scientists have applied sediment core analysis to evaluate geochronologically the pollution record in a particular catchment area (Burton 1991; Masunaga et al. 1999; Begum et al. 2009). Geochronology information from sediment core is largely obtained from radioactive dating (Jeter 1999). In the absence of radioactive dating, echo-sounding may be indirectly used. Echo-sounding has been used to map bottom sediments and to provide depth details of a reservoir (Odhiambo and Boss 2004; Balan et al. 2013). Where change in depth of a reservoir could be established and reasonably linked to sediment build-up, the rate of sedimentation so estimated could be applied to deduce useful information on geochronology.

The present study applied the concept of sediment core profile to evaluate heavy metal contamination in the Lake Amponsah at Bibiani, a mining enclave in Ghana. Gold mining in Bibiani dates back to 1900s. There has been several re-mining and closure at Bibiani since 1913. Bibiani Limited one of the foremost mining companies to begin mining operations in the town, embarked solely on underground operations until shutdown in 1961. Between 1987 and 2013, several other mining companies had operated at the Bibiani mines for comparatively different periods. Historically, $\mathrm{Hg}$ was applied in large-scale gold mining at Bibiani. Although $\mathrm{Hg}$ is presently highly regulated (Mercury Act 1989) and no longer used in large-scale operations, small-scale gold miners continue to illicitly apply it. This is because $\mathrm{Hg}$ provides a cheap and effective means to extract gold from poor quality gold ores. The continuous application of Hg however raises serious environmental health concerns. For instance, $\mathrm{Hg}$ is easily converted to methyl- $\mathrm{Hg}$ in sediment. The bioaccumulation of methyl- $\mathrm{Hg}$ in fish was implicated in the Minamata disease (Harada 1995). Inorganic $\mathrm{Hg}$ may also cause various neurotoxic effect and damages to human organs such as the kidney (Langford and Ferner 1999). This study provided a retrospective analysis of contamination from heavy metals $(\mathrm{Hg}, \mathrm{Pb}$, $\mathrm{As}, \mathrm{Cu}$ and $\mathrm{Cd}$ ) in the Bibiani mining district in Ghana, applying sediment core analysis. Contamination trends were established and discussed from the perspective of local policies governing mining in Ghana.

\section{Methodology \\ Study area}

The study was conducted at Bibiani (Fig. 1), a mining township in Ghana, situated at $6.47^{\circ}$ North latitude, $2.33^{\circ}$ West longitude and 260 meters elevation above sea level. Gold mining is the main industrial activity at Bibiani; both large-scale mining and artisanal small-scale mining (including illicitly operated ones known locally as galamsey) are practiced in this community. Bibiani has a population of approximately 26,000 (BABDA 2006). A key feature at Bibiani is Lake Amponsah, a man-made reservoir, which was constructed by the then State Gold Mining Corporation, for domestic water use. It had a mean depth of approximately $4.00 \mathrm{~m}$ at the time it was constructed in 1960. The Lake covered an area of $0.051 \mathrm{~km}^{2}\left(51,156.67 \mathrm{~m}^{2}\right)$ and had a storage capacity of about $168,205.40 \mathrm{~m}^{3}$ (37 million gallons) of water. It also receives storm runoff from within its immediate catchment areas; notably, the Amponsah stream that drains the community.

\section{Sampling}

Sediment cores were sampled to a depth of $30 \mathrm{~cm}$ from three sites within Lake Amponsah, applying a PVC corer of $5 \mathrm{~m}$ length and $2 \mathrm{~cm}$ diameter. After sampling, the sediment cores were carefully removed from the corer and allowed to dry in ambient air for $72 \mathrm{~h}$. The dried cores were then sliced into equal sections of $5 \mathrm{~cm}$ each.

\section{Sample preparation and laboratory analysis}

Sliced sediment samples were air dried at room temperature for $4 \mathrm{~h}$ in the laboratory. With the aid of a mortar and pestle, each slice was ground into fine powder and 


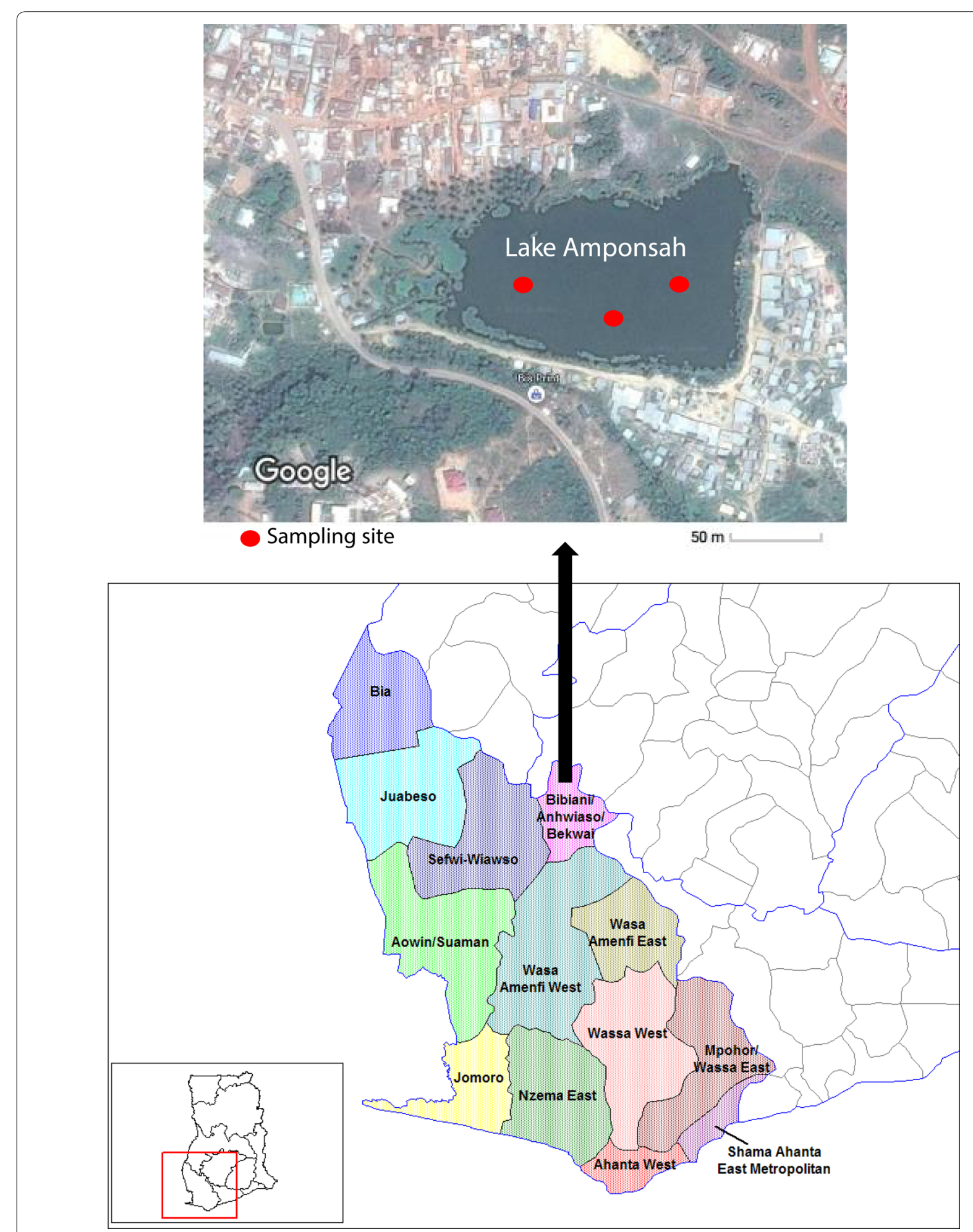

Fig. 1 Study location in Ghana (Map of lake was derived from Google Map)

sieved using a mesh of $2 \mathrm{~mm}$ diameter. One gram of the ground sediment sample was wet digested using $10 \mathrm{~mL}$ of concentrated $\mathrm{HClO}_{4}(70 \%), 10 \mathrm{~mL}$ of concentrated
$\mathrm{HCl}(38 \%)$ and $0.2 \mathrm{~mL}$ of $\mathrm{H}_{2} \mathrm{O}_{2}(30 \%)$ (which served as a catalyst). The chemicals were all of analytical grade from Fisher Scientific, UK. The digestion was done on a 
hot plate in a fume chamber. The digested mixture was allowed to cool to room temperature, filtered and then made up to $100 \mathrm{~mL}$ with de-ionize water.

Arsenic concentration was determined applying the Palintest (Wagtech) method (Bralatei et al. 2015). Fifty milliliters of the digest was transferred into a $200 \mathrm{~mL}$ conical flask. One sachet of Wagtech A1 (sulphamic acid) and 1 tablet of Wagtech A2 (sodium borohydride $<10 \%$ ) were added to the solution and glassware corked immediately. The tablet was allowed to dissolve, well mixed, after which the As content of the sample was determined using an Arsenator (PTW 10010 Wagtech Potalab ${ }^{\circledR}$, Palintest Ltd). The detection limit of As was $0.01 \mu \mathrm{g} / \mathrm{g}$.

The concentrations of $\mathrm{Cu}, \mathrm{Cd}, \mathrm{Hg}$ and $\mathrm{Pb}$ were analysed by Anodic stripping voltammetry (ASV) method, using a Cogent Environmental PDV 6000 plus metals analyser (Butterfield 2009). The device was interfaced to a computer via the VAS (Voltammetric Analysis System) software and appropriate run method was created for each metal. The PDV 6000 plus device was calibrated using standard CLAC electrolyte (chloride-acetate buffer electrolyte) of concentration range $800 \mathrm{ppb}-20 \mathrm{ppm}$. Five milliliters of digested sample solution was pipetted and made up to $10 \mathrm{~mL}$ using de-ionized water. Ten milliliters CLAC electrolyte was added to give a total volume of $20 \mathrm{~mL}$ in a clean analytical cup. The addition of the electrolyte was to ensure that the solution was sufficiently conductive to enhance plating processes and permitting the control of the electrode potential. The sample was then run using VAS and sample voltammogram generated showing peaks for $\mathrm{Cd}, \mathrm{Cu}, \mathrm{Pb}$ and $\mathrm{Hg}$. The standard solution was re-run after analyzing every five samples for quality control purposes. The detection limit of $\mathrm{Cd}, \mathrm{Pb}$, $\mathrm{Cu}$ and $\mathrm{Hg}$ was $0.01 \mu \mathrm{g} / \mathrm{g}$.

\section{Rate of sedimentation}

The rate of sedimentation in Lake Amponsah was estimated based on change in depth of the Lake with time. The average depth of the Lake at the time it was constructed in 1960 was $4 \mathrm{~m}(400 \mathrm{~cm})$. The current average depth of the Lake was measured applying a depth sounder device (Hondex Digital Depth Sounder). This device functions by sending laser beam from the surface of the Lake down to the Lake floor. The beam is then reflected back to the device and the distance travelled is estimated as depth. The depth measurement was taken at 50 different points across the Lake's surface and the average value estimated. Assuming change in depth of the reservoir was due to sediment buildup and net effect from evaporation was minimal, the annual rate of sedimentation in the Lake was estimated as follows: (Initial depth-current depth)/Age of lake. Therefore,

$$
\begin{aligned}
& \text { the annual rate of sedimentation }= \\
& \qquad(4 \mathrm{~m}-\text { Current depth }) /(2014-1960)
\end{aligned}
$$

\section{Statistical analysis}

Heavy metal concentrations were expressed as mean \pm standard error of mean (SEM). Pearson correlation was applied to examine specific relationships among the metals at the upper and lower segments of the sediment core.

\section{Results and discussion}

\section{Rate of sedimentation in lake Amponsah}

The current average depth of Lake Amponsah was estimated as $305 \mathrm{~cm}(10.01 \mathrm{ft}$.). Applying the Eq. 1, the rate of sedimentation per year was then estimated as $1.76 \mathrm{~cm}$. Thus, each $5 \mathrm{~cm}$ slice of sediment core corresponds to approximately 3 years of sedimentation. In effect, depths of $5,10,15,20,25,30$ and $35 \mathrm{~cm}$ correspond to year 2011, 2008, 2005, 2002, 1999, 1996 and 1993, respectively. Sedimentation rate of $1.76 \mathrm{~cm} / \mathrm{y}$ is generally high compared to most of the rates reported in literature. For instance, the Gorgan Bay in Iran was reported to be undergoing sedimentation at a rate of 1.4 to $2.45 \mathrm{~mm} / \mathrm{y}$ (Karbassi and Amirnezhad 2004); Lake Ontario in Canada-0.02 to $0.11 \mathrm{~cm} / \mathrm{y}$ (Farmer 1978); and Lake Taihu in China0.6 to $3.6 \mathrm{~mm} / \mathrm{y}$ (Qin et al. 2007). It suggests that Lake Amponsah was undergoing rapid siltation, quite comparable to the maximum rates of sedimentation reported in North Indian lakes, some measuring up to $1.5 \mathrm{~cm} / \mathrm{y}$ (Kumar et al. 2007). Wastewater from residential facilities close to Lake Amponsah, runoff from agricultural farmlands and effluent discharged from small-scale mining activities, in addition to issues of erosion, were probably some of the key factors that contributed to the rapid siltation of the Lake.

\section{Depth profile of heavy metals in sediment core}

The average concentrations (dry weight) of heavy metals in the different segments of the sediment cores varied as follows: $\mathrm{Hg} 0.018 \pm 0.005-0.025 \pm 0.005 \mathrm{mg} /$ kg; Cd $0.16 \pm 0.03-0.38 \pm 0.18 \mathrm{mg} / \mathrm{kg} ; \mathrm{Pb} 0.98 \pm 0.19-$ $2.62 \pm 0.46 \mathrm{mg} / \mathrm{kg} ; \mathrm{Cu} 1.60 \pm 0.40-3.17 \pm 0.85 \mathrm{mg} / \mathrm{kg}$; and As $43.00 \pm 16.26-87.67 \pm 6.98 \mathrm{mg} / \mathrm{kg}$. The minimum mean concentration of $\mathrm{Hg}$ occurred at $5 \mathrm{~cm}$ depth of the sediment cores, while $\mathrm{Cd}, \mathrm{Pb}, \mathrm{Cu}$ and As concentrations were lowest at $25,30,30$ and $20 \mathrm{~cm}$ depths of the sediment cores, respectively. With the exception of $\mathrm{Hg}$, all the heavy metals decreased in concentration with depth, and corresponded to increasing contamination from $\mathrm{Cd}, \mathrm{Pb}, \mathrm{Cu}$ and As from the early 1990s-2010s (Fig. 2). Mercury concentrations however marginally declined during this period, such that the least concentration was measured in the upper layers of the sediment core. This 


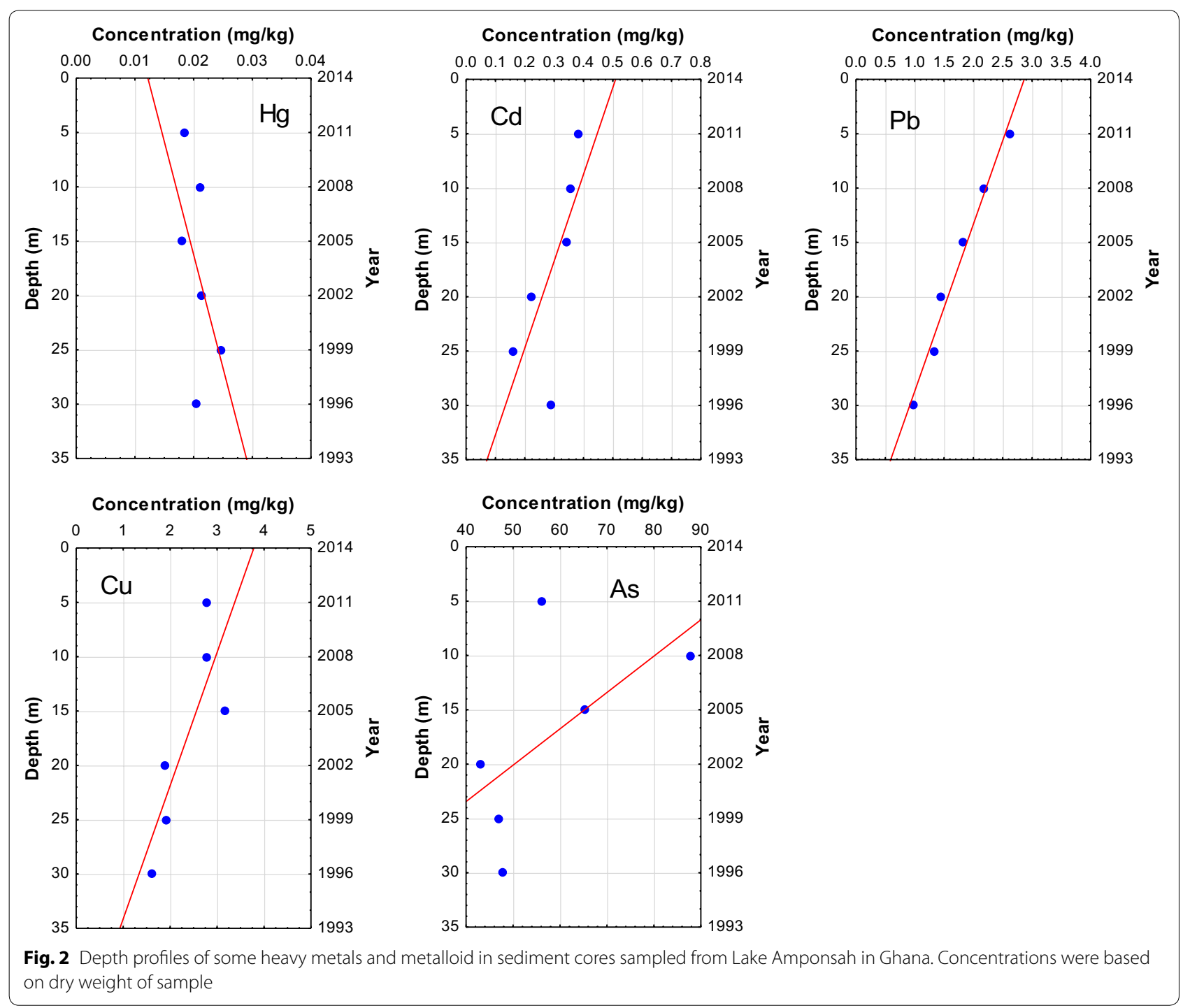

finding is consistent with recent decline in sediment $\mathrm{Hg}$ levels in Lake Bosomtwe in Ghana (Poste et al. 2012), but quite at variance with reported illicit application of $\mathrm{Hg}$ by illegal small-scale miners (Donkor et al. 2006b; Hilson et al. 2007). Two main factors may have contributed to the decreasing trend in $\mathrm{Hg}$ concentration. First, contributions from large-scale mining have curtailed, following the Hg legislation in Ghana (Mercury Act 1989). Largescale operators complied with new laws and regulations controlling the use of $\mathrm{Hg}$, having switched to the use of cyanide in gold processing. Second, even though smallscale operators continue to illicitly use $\mathrm{Hg}$, the difficulty in obtaining the metal as a result of present regulations has forced them to recover and reuse the Hg. The smallscale miners indicated that $\mathrm{Hg}$ has become very expensive and difficult to obtain, hence, have devised measures for the economical use of the metal. They have resorted to procuring a small device called "Retort", which is used to recover most of the $\mathrm{Hg}$ applied (Fig. 3). Thus, less $\mathrm{Hg}$ was allowed to directly escape into soil and sediment media. This may have contributed to the marginal decline in concentration of the metal in sediment with time. Nevertheless, small-scale miners risked direct exposure to the $\mathrm{Hg}$ during their operations, especially from dermal contact (galamsey operators directly handled $\mathrm{Hg}$ in their palm - this was observed during the field visit) (Fig. 3).

The increasing levels of the remaining metals in recent years, particularly As, may pertain to releases as by-products via the mine wastes. Given the haphazard nature of galamsey operations, the fine grinds that may contain some of these metals are all released directly into water bodies. Therefore the upsurge of galamsey operations with time has invariably generated increasing levels of contamination from various heavy metals 

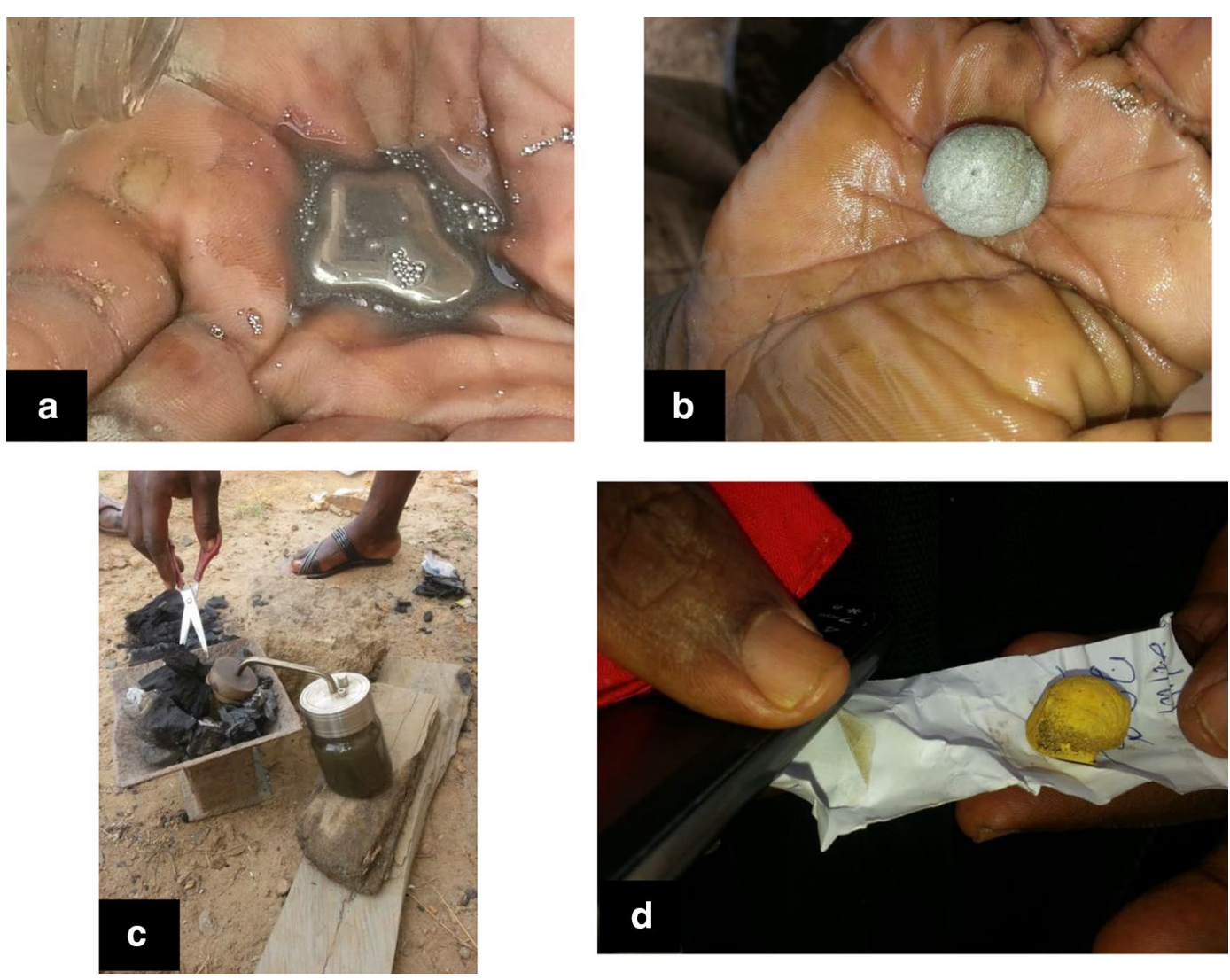

Fig. 3 Crude method of gold processing using mercury by small scale miners. a Mercury being handled by a small-scale miner in the palm; $\mathbf{b}$ mixture of mercury and gold ore; c charcoal heating of gold amalgam in retort device; $\mathbf{d}$ gold separated from the amalgam

as one traversed upwards along the sediment core. The comparatively high levels of As in the sediment core was related to the gold-bearing ore, which is rich in arsenopyrite (FeAsS) (Antwi-Agyei et al. 2009). Considering that small-scale miners did not treat mine wastes, As in fine grinds were released directly into the environment, while exposure and subsequent oxidation of pyrite $\left(\mathrm{FeS}_{2}\right)$ were likely to cause acid mine drainage (AMD). The AMD potentially mobilized toxic metals from the mine wastes and soils resulting in increasing levels of these toxic elements in the sediment over time.

\section{Relationships between metals}

Mercury correlated positively with As (though only moderately), but negatively with $\mathrm{Cd}, \mathrm{Pb}$ and $\mathrm{Cu}$ (Table 1 ). It probably suggested that $\mathrm{Hg}$ was used in extracting gold from the arsenopyrite gold bearing ore (Valdes et al. 2005; Quarshie et al. 2011). Two notable correlations were apparent, considering the correlation coefficients. Lead correlated strongly with $\mathrm{Cu}(\mathrm{r}=0.74)$, besides the moderate positive correlation observed between $\mathrm{Hg}$ and $\mathrm{As}$ $(\mathrm{r}=0.44)$ (Table 1). Following this observation, the relationships between $\mathrm{Pb}$ and $\mathrm{Cu}$, and $\mathrm{Hg}$ and As were each analyzed separately for the top half (i.e. $<15 \mathrm{~cm}$ ), as well as the bottom half (i.e. $>15 \mathrm{~cm}$ ) of the sediment core. The correlation between As and $\mathrm{Hg}$ was much pronounced and relevant at the bottom half $(>15-30 \mathrm{~cm})$ of the sediment core $(\mathrm{r}=0.88)$ (Fig. 4). Arsenic and Hg however did not correlate at the top half $(0-15 \mathrm{~cm})$ of the sediment core. This may point to a recent relative increase or decrease in contamination from $\mathrm{As}$ or $\mathrm{Hg}$, culminating in the contrasting relationship between the two metals at the top half of the sediment core. Considering the arsenopyrite nature of gold ore in the Bibiani mining district, As levels in sediment were expected to naturally increase with increased mining activity. The absence of correlation with $\mathrm{Hg}$ therefore suggests that there was not a corresponding increase in contamination from $\mathrm{Hg}$. When pollutants correlate, it presupposes that their sources of contamination might be similar or related. Thus, the high correlation between As and $\mathrm{Hg}$ in the bottom half of the sediment core suggested a historically relevant association 
Table 1 Correlation matrix of various metals and metalloid in sediment core

\begin{tabular}{lccccc}
\hline & Hg & Cd & Pb & Cu & As \\
\hline $\mathrm{Hg}$ & 1.00 & & & & \\
$\mathrm{Cd}$ & -0.25 & 1.00 & & & \\
$\mathrm{~Pb}$ & -0.26 & 0.20 & 1.00 & & \\
$\mathrm{Cu}$ & -0.30 & 0.27 & $0.74^{*}$ & 1.00 & \\
As & $0.44^{* *}$ & 0.15 & -0.10 & 0.06 & 1.00 \\
\hline
\end{tabular}

Significance level: * $p<0.05 ;{ }^{* *} p<0.10$

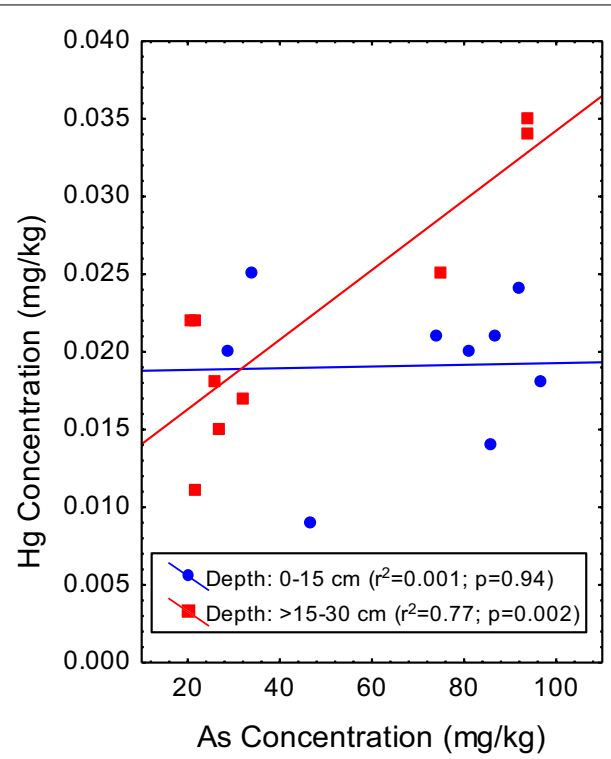

Fig. 4 Regression between $\mathrm{Hg}$ and As at the top $(0-15 \mathrm{~cm})$ and down $(>15-30 \mathrm{~cm})$ portions of the sediment core

between these two metals in the Lake Amponsah watershed. Historically, there was liberal application of $\mathrm{Hg}$ in gold extraction from the arsenopyrite based ores in that region. Hence, the correlation between As and Hg. Lead and $\mathrm{Cu}$, on the other hand, strongly correlated at both the top and bottom halves of the sediment core $(\mathrm{r} \approx 0.70$ in each case) (Fig. 5). The sources of these two metals were, thus, presumably similar. To the extent that $\mathrm{Pb}$ and $\mathrm{Cu}$ are not major constituents regarding the mineralogy of the Bibiani area (Quarshie et al. 2011), presumably, the contamination from these two metals were from anthropogenic sources. Particularly, evidence of dumping of solid wastes into the Lake was quite rife in the area. It was also found that wastewater from the community and nearby agro-industrial activities mostly ended up in the Lake. Additionally, runoffs of agrochemical residues from nearby farms were likely to have contributed to the input of some of these metals into Lake Amponsah (ObiriDanso et al. 2011).

\section{Policy implications}

With the exception of $\mathrm{Hg}$, there were clear trends of increasing concentrations of heavy metals over the past two decades from the 1990s to 2010s. Mercury concentrations marginally declined over the same period. It could be presumed that the Mercury Act 1989 (PNDC Law 217) highly regulating the use of $\mathrm{Hg}$ in Ghana effective from 1989 has helped immensely in achieving this marginal reduction for Hg. Despite the illicit access and application of $\mathrm{Hg}$ by galamsey miners, the existing regulation of the metal has forced the small-scale miners to recover and reuse the metal in their operations, limiting the direct escape of $\mathrm{Hg}$ into the environment. The need to regularize operations of small-scale miners led to the legislation of the Small-Scale Gold Mining Law (PNDC Law 218) in 1989, now repealed, but the tenets continued in the Minerals and Mining Act, 2006 (Act 703). Under this law, small-scale miners are required to register their concessions, obtain a license before they can operate and supported with the establishment of support centres for small-scale mining. It was anticipated that this arrangement would help regularize the small-scale mining industry and reduce environmental impact. Unfortunately, only few small-scale miners have availed themselves to this system of regulation. In 2001, 420 small-scale mining operations were registered (Amankwah and Anim-Sackey 2003), but this reduced to 300 ten years later in 2011 (Adu-Gyamfi 2011). The number of people engaged in small-scale mining business nevertheless have risen tenfold from 100,000 in 2001 (Amankwah and Anim-Sackey 2003) to about 1,000,000 in 2015 (Kwatia 2015). A large proportion of the smallscale miners presently evades registration and operates outside the mining regulations. Many acquire their concessions illegitimately and therefore are unable to register and acquire the necessary license, while others avoid registration to evade tax. Therefore in reality, the regulations to align small-scale mining practices with normal mining operations have largely not achieved the intended purpose. The increasing unregulated activity in this sector over the past 20 years or so has resulted in the degradation of large tracts of land and release of various metal contaminants into nearby water bodies. This has also resulted in accelerated sedimentation of local water bodies. The increasing trends of the various heavy metals in the sediment core and relatively high rate of sedimentation in the Lake Amponsah were, thus, a direct consequence of policy failure in regulating small-scale mining activities in Ghana. A key policy reform should concern $\mathrm{Hg}$ accessibility issues, considering that without access to $\mathrm{Hg}$ illicit small-scale mining would not proceed. The Ghana Minerals and Mining Act, 2006 (Act 703) provides for small-scale miners to purchase from an authorized 


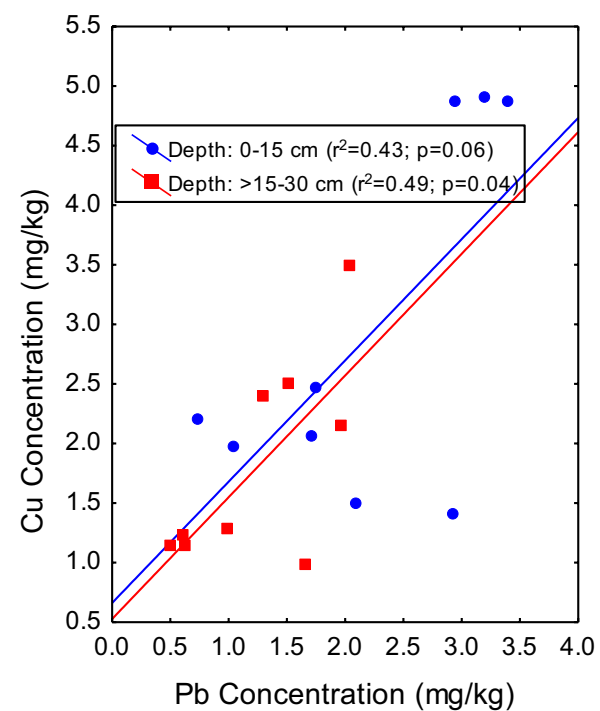

Fig. 5 Regression between $\mathrm{Cu}$ and $\mathrm{Pb}$ at the top $(0-15 \mathrm{~cm})$ and down $(>15-30 \mathrm{~cm})$ portions of the sediment core

$\mathrm{Hg}$ dealer the quantities of $\mathrm{Hg}$ that may be reasonably necessary for the mining operations of the small scale miner. Unfortunately, this has been heavily abused, with $\mathrm{Hg}$ illicitly accessible from unauthorized dealers. Going forward, stricter measures are required to phase out the application of $\mathrm{Hg}$ in small-scale mining in Ghana. This may entail eventual banning of the use of $\mathrm{Hg}$ in the local mining industry, which would necessitate an amendment in the Minerals and Mining Act. Such policy considerations are consistent with the global policy direction on $\mathrm{Hg}$, which seeks to curtail the global use and emissions of $\mathrm{Hg}$. A key aspect of this policy is to assist developing countries in phasing out the toxic heavy metal in industrial processes and in artisanal gold mining in Africa, Asia and Latin America (UNEP 2013).

\section{Conclusion}

Lake Amponsah, in the Bibiani mining district in Ghana, was found to be undergoing quite accelerated rate of sedimentation with an average buildup of approximately $5 \mathrm{~cm}$ of sediment every 3 years. The concentrations of $\mathrm{Pb}, \mathrm{Cu}$, $\mathrm{Cd}$ and As increased in upper layer sediments, reflecting greater contamination from these metals in recent times. The concentration trend of $\mathrm{Hg}$ was contrary to the other metals, despite the continuous application of $\mathrm{Hg}$ by smallscale miners in gold extraction. It was concluded that the marginal decline in $\mathrm{Hg}$ concentration in sediment over the past two decades in Ghana was partly due to a somewhat $\mathrm{Hg}$ recovery process integrated into the small-scale mining extraction process, limiting direct escape of $\mathrm{Hg}$ into the environment. Nonetheless, there could be direct exposure to $\mathrm{Hg}$ from dermal contact and inhalation. The $\mathrm{Hg}$ legislation could help in reducing environmental contamination from $\mathrm{Hg}$ in Ghana if it could be enforced to the latter, where small-scale miners do not have access to the metal. The haphazard nature of small-scale mining, non-treatment of mine wastes and release of mine wastes containing pyrites into water bodies created conditions rife for acid mine drainage, which potentially mobilized toxic metals such as $\mathrm{Pb}, \mathrm{Cu}, \mathrm{Cd}$ and As eventually into sediments, with trends of increasing concentrations over time. The present situation provides evidence of the environmental damage associated with small-scale mining in Ghana and other West African countries.

\section{Abbreviations}

ASV: anodic stripping voltammetry; VAS: voltammetric analysis system; CLAC electrolyte: chloride-acetate buffer electrolyte; AMD: acid mine drainage.

\section{Authors' contributions}

All authors read and approved the final manuscript.

\section{Author details}

${ }^{1}$ Department of Environmental Science, College of Science, Kwame Nkrumah University of Science and Technology, Kumasi, Ghana. ${ }^{2}$ Institute for Environment and Sanitation Studies, University of Ghana, Legon, Ghana. ${ }^{3}$ Department of Chemistry, College of Science, Kwame Nkrumah University of Science and Technology, Kumasi, Ghana. ${ }^{4}$ Chemicals Control and Management Centre, Environmental Protection Agency, Accra, Ghana.

\section{Acknowledgements}

We acknowledge laboratory support from Envaserv Research Consult in Accra, Ghana, where the samples were analyzed.

\section{Competing interests}

The authors declare that they have no competing interests.

Received: 13 February 2016 Accepted: 29 March 2016

Published online: 12 April 2016

\section{References}

Adu-Gyamfi Y (2011) Small-scale mining business in Ghana: challenges and prospects. http://opinion.myjoyonline.com/pages/feature/201112/77486. php. Accessed 12 Nov 2015

Ahmad K, Carboo D (2000) Speciation of As (III) and As (V) in some Ghanaian gold tailings by a simple distillation method. Water Air Soil Pollut 122:317-326

Amankwah RK, Anim-Sackey C (2003) Strategies for sustainable development of the small-scale gold and diamond mining industry of Ghana. Resour Policy 29(3):131-138

Amonoo-Neizer EH, Nyamah D, Bakiamoh SB (1995) Mercury and arsenic pollution in soil and biological samples around the mining town of Obuasi, Ghana. Water Air Soil Pollut 91:363-373

Antwi-Agyei P, Hogarh JN, Foli G (2009) Trace elements contamination of soils around gold mine tailings dams at Obuasi, Ghana. Afr J Environ Sci Technol 3(11):353-359

Asante KA, Agusa T, Subramanian A, Ansa-Asare OD, Biney CA, Tanabe S (2007) Contamination status of arsenic and other trace metals in drinking water and residents from Tarkwa, a historic mining township in Ghana. Chemosphere 66:1513-1522

Audry S, Schäfer J, Blanc G, Jouanneau JM (2004) Fifty-year sedimentary record of heavy metal pollution $(\mathrm{Cd}, \mathrm{Zn}, \mathrm{Cu}, \mathrm{Pb})$ in the Lot River reservoirs (France). Environ Pollut 132(3):413-426 
Awumbila B (1996) Acaricides in tick control in Ghana and methods of application. Trop Anim Health Prod 28(2):10-16

BABDA (2006) Bibiani-Anwhiaso-Bekwai District assembly's medium term development plan (2006-2007) document, pp 15-20

Balan MS, Das CDA, Khandelwal M, Chaudhari P (2013) Review of various technologies for depth measurement in estimating reservoir sedimentation. Int J Eng Res Technol 2(10):223-228

Bamford SA, Osae E, Aboh I, Biney CA, Antwi LA (1990) Environmental impact of the gold mining industry in Ghana. Biol Trace Elem Res 26(1):279-285

Begum A, Ramaiah M, Khan HI, Veena K (2009) Heavy metal pollution and chemical profile of Cauvery River water. E-J Chem 6(1):47-52

Bortey-Sam N, Nakayama SM, Akoto O, Ikenaka Y, Fobil JN, Baidoo E, Mizukawa $\mathrm{H}$, Ishizuka M (2015) Accumulation of heavy metals and metalloid in foodstuffs from agricultural soils around Tarkwa area in Ghana, and associated human health risks. Int J Environ Res Publ Health 12(8):8811-8827

Bralatei E, Lacan S, Krupp EM, Feldmann J (2015) Detection of inorganic arsenic in rice using a field test kit: a screening method. Anal Chem 87(22):11271-11276

Burton GA Jr (1991) Assessing freshwater sediment toxicity. Environ Toxicol Chem 10:1585-1627

Butterfield M (2009) On-site measurement of metals in water samples taken from Nant Gwydyr and Llyn Gerionydd using a cogent environmental PDV 6000 plus metals analyser. In: Water Institute of Southern Africa \& International Mine Water Association: proceedings, international mine water conference, Document Transformation Technologies, pp 234-239. http://www.imwa.info/docs/imwa_2009/IMWA2009_Butterfield.pdf. Accessed 1 June 2014

Donkor AK, Bonzongo JCJ, Nartey VK, Adotey DK (2005) Heavy metals in sediments of the gold mining impacted Pra River basin, Ghana, West Africa. Soil Sedim Contam 14(6):479-503

Donkor AK, Bonzongo JC, Nartey VK, Adotey DK (2006a) Mercury in different environmental compartments of the Pra River Basin, Ghana. Sci Total Environ 368(1):164-176

Donkor AK, Nartey VK, Bonzongo JC, Adotey DK (2006b) Artisanal mining of gold with mercury in Ghana. West Afr J Appl Ecol 9(1)

Down CG, Stocks J (1978) Environment impact of mining. Applied Science Publish Ltd, London, p 371

Farmer JG (1978) The determination of sedimentation rates in Lake Ontario using the ${ }^{210} \mathrm{~Pb}$ dating method. Can J Earth Sci 15(3):431-437. doi:10.1139/e78-047

Harada M (1995) Minamata disease: methylmercury poisoning in Japan caused by environmental pollution. Crit Rev Toxicol 25(1):1-24

Hilson G, Hilson CJ, Pardie S (2007) Improving awareness of mercury pollution in small-scale gold mining communities: challenges and ways forward in rural Ghana. Environ Res 103(2):275-287

Hogarh JN, Seike N, Kobara Y, Ofosu-Budu GK, Carboo D, Masunaga S (2014) Atmospheric burden of organochlorine pesticides in Ghana. Chemosphere 102:1-5

Jeter HW (1999) Determining the ages of recent sediments using measurements of trace radioactivity. Workshop of the Nuclear Regulatory Commission, Region 1, in June 1999, in Baltimore. https://www.iadc-dredging. com/ul/cms/terraetaqua/document/0/9/0/90/90/1/terra-et-aquanr78-03.pdf. Accessed 1 Dec 2015
Karbassi AR, Amirnezhad R (2004) Geochemistry of heavy metals and sedimentation rate in a bay adjacent to the Caspian Sea. Int J Environ Sci Technol 1(3):191-198

Kumar B, Rai SP, Nachiappan RP, Kumar SU, Singh S, Diwedi VK (2007) Sedimentation rate in North Indian lakes estimated using $137 \mathrm{Cs}$ and $210 \mathrm{~Pb}$ dating techniques. Curr Sci 92(10):1416-1420

Kwatia G (2015) Small scale mining: a menace to society or a key to national development. http://thebftonline.com/features/opinions/15149/Smallscale-mining-a-menace-to-society-or-a-key-to-national-development. html. Accessed 27 Nov 2015

Langford NJ, Ferner RE (1999) Toxicology of mercury. J Hum Hypertens 13:651-656

Masunaga S, Yao Y, Ogura I, Nakai S, Kanai Y, Yamamuro M, Nakanishi J (1999) Historical contribution of different sources to environmental dioxin pollution estimated from the Lake Shinji sediment core. Organohalogen Compd 43:383-386

Mercury Act (1989) Government of Ghana, P. N. D. C. Law 217. http://www.epa. gov.gh/ghanalex/acts/Acts/MERCURYHG\%20ACT,1989.pdf. Accessed 15 Nov 2015

Nartey VK, Klake RK, Doamekpor LK, Sarpong-Kumankomah S (2012) Speciation of mercury in mine waste: case study of abandoned and active gold mine sites at the Bibiani-Anwiaso-Bekwai area of South Western Ghana. Environ Monit Assess 184(12):7623-7634

Ntow WJ, Gijzen HJ, Kelderman P, Drechsel P (2006) Farmer perceptions and pesticide use practices in vegetable production in Ghana. Pest Manag Sci 62(4):356-365

Obiri-Danso K, Adonadaga MG, Hogarh JN (2011) Effect of agrochemical use on the drinking water quality of Agogo, a tomato growing community in Ashanti Akim, Ghana. Bullet Environ Contam Toxicol 86(1):71-77

Odhiambo BK, Boss SK (2004) Integrated echo sounder, GPS, and GIS for reservoir sedimentation studies: examples from two Arkansas Lakes. J Am Water Resour Assoc 40(4):981-997

Poste AE, Muir DC, Otu MK, Hall Rl, Hecky RE (2012) Past and present mercury flux to a West African crater lake (Lake Bosomtwe/Bosumtwi, Ghana). Sci Total Environ 420:340-344

Qin B, Xu P, Wu Q, Luo L, Zhang Y (2007) Environmental issues of Lake Taihu, China. Hydrobiologia 581(1):3-14

Quarshie E, Nyarko BJB, Serfor-Armah Y (2011) Studies of the levels of some toxic elements in soil and tailings from Bibiani mining area of Ghana. Res J Environ Earth Sci 3:512-520

Spencer KL, Macleod CL (2002) Distribution and partitioning of heavy metals in estuarine sediment cores and implications for the use of sediment quality standards. Hydrol Earth Syst Sci 6:989-998

UNEP (2013) Mercury: time to act. http://www.unep.org/PDF/PressReleases/ Mercury_TimeToAct.pdf. Accessed 3 Dec 2015

Valdes J, Vargas G, Sifeddine A, Ortlieb L, Guinez M (2005) Distribution and enrichment evaluation of heavy metals in Mejillones Bay $\left(23^{\circ} \mathrm{S}\right)$, Northern Chile: geochemical and statistical approach. University of Antofagasta, Antofagasta

\section{Submit your manuscript to a SpringerOpen ${ }^{\circ}$ journal and benefit from:}

- Convenient online submission

- Rigorous peer review

- Immediate publication on acceptance

- Open access: articles freely available online

- High visibility within the field

- Retaining the copyright to your article

Submit your next manuscript at $>$ springeropen.com 